\title{
Andrzej RUPRECHT
}

SUPERNUMERARY PREMOLAR IN MUSTELA PUTORIUS L I N NAEUS, 1758

NADLICZBOWY PRZEDTRZONOWIEC U MUSTELA PUTORIUS LIN NAEUS, 1758

Dental anomalies have not infrequently been observed in Mustelidae. Cases of supernumerary upper incisors in captive specimens of $M$. putorius, and retained incisors (retention $-\mathrm{I}^{1}, \mathrm{I}^{1}$ and $\mathrm{I}_{1}, \mathrm{I}_{1}$ ) in Mustela vison domestica $\mathrm{Hal}$ te $\mathrm{n}$ or $\mathrm{th}, 1955$, were described by $\mathrm{R}$ e i $\mathrm{nw}$ a ld $\mathrm{t}$ (1958). Supernumerary premolars, and $\mathrm{M}^{2}$ in Meles meles ( $\mathrm{L}$ i nn a e us, 1758) were described by Fullagar et al., (1960), and the occurrence of supernumerary premolars in Lutra canadensis ( $\mathrm{S} \mathrm{chreber}, 1776$ ) by De a d e rn (1960).

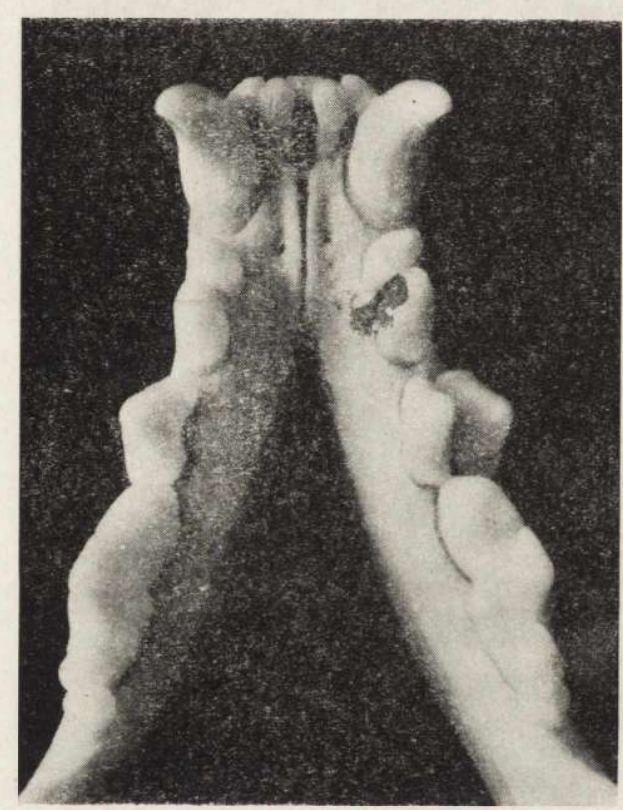

M. putorius (coll. no. 409, o ad, Cb. $-67.7 \mathrm{~mm}$ ), was killed on March 19th 1962 at Niestuszewo (in Aleksandrów Kujawski district, Bydgoszcz province). In the right half of the mandibula there were two teeth $\mathrm{Pm}_{3}$ lying parallel to each other (Fig. 1). They have separate sockets and differ slightly in size (the outer tooth being larger). The appearance and structure of the teeth and the animal's age indicate that these two teeth belong to the final generation.

Fig. 1. Mandibula of M. putorino. Supernumerary premolar is visible.

\section{REFERENCES}

R e inwaldt E., 1958: Uber- und unterzählige Schneidezähne bei Musteliden. Säugetierkundl. Mitt., 6, 3. 97-100. Stuttgart. F u 11 a g a r P. J., R o g e r s T. H. 8. M a n sfield D., 1960: Supernumeratory teeth in the Badger (Meles meles). Proc. zool. Soc. Lond. 133, 3: 494. D e a d e r n L. C., 1960: Extra premolars in the River otter (Lutra canadensis). J. Mammal., 35, 1: 125-126. Lawrence.

Mammals Research Institute, Polish Academy of Sciences, Białowieża.

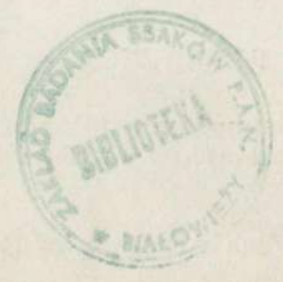

